Editorial

\title{
Innovation and Entrepreneurship for Well-Being and Sustainability
}

\author{
Olimpia Meglio $^{1, * \mathbb{D}}$ and Nadia Di Paola ${ }^{2}$ \\ 1 Department of Law, Economics, Management and Quantitative Methods (DEMM), University of Sannio, \\ 82100 Benevento, Italy \\ 2 Department of Economics, Management and Institutions (DEMI), University of Naples "Federico II", \\ 80138 Napoli, Italy; ndipaola@unina.it \\ * Correspondence: meglio@unisannio.it
}

Citation: Meglio, O.; Di Paola, N. Innovation and Entrepreneurship for Well-Being and Sustainability. Sustainability 2021, 13, 9154. https:/ / doi.org/10.3390/su13169154

Received: 2 August 2021

Accepted: 13 August 2021

Published: 16 August 2021

Publisher's Note: MDPI stays neutral with regard to jurisdictional claims in published maps and institutional affiliations.

Copyright: (c) 2021 by the authors. Licensee MDPI, Basel, Switzerland. This article is an open access article distributed under the terms and conditions of the Creative Commons Attribution (CC BY) license (https:// creativecommons.org/licenses/by/ $4.0 /)$.

\section{Introduction}

Entrepreneurship, innovation, well-being, and sustainability represent the four pillars inspiring our call for papers and driving this Special Issue (hereafter SI) [1]. While drafting the call for papers, we were influenced by the huge change our lives were undergoing due to COVID-19 [2]. The pandemic has brought attention to the importance of entrepreneurship and innovation, to design a future where sustainability and well-being are pursued conjointly [3]. More specifically, the pandemic has brought to our attention the importance of innovating towards sustainability and well-being, and accelerating multiple processes underway [4]. What the next normal will look like is expected to be shaped by entrepreneurship and innovation that, together, will foster societal growth with well-being and sustainability serving as key drivers. Our call for papers appears therefore particularly timely.

Our call got interest from scholars from different geographical areas, touching different topics with different perspectives and research approaches. In this editorial, we provide our own reading on these papers, highlighting how they relate to one another and how they help us envision multiple avenues for future research. Our Special Issue will hopefully raise additional questions rather than providing any definitive answers and we aspire to the metaphor of being a transit stop along a broader and longer collective journey towards a better future.

\section{Innovation, Entrepreneurship, Well-Being, and Sustainability as Umbrella Constructs}

The emergence and rapid diffusion of the COVID-19 pandemic has brought attention to the importance of pursuing sustainable choices, with a focus on well-being in a broad sense. In this regard, entrepreneurship and innovation play a crucial role in designing a future where the principles of well-being and sustainability are more deeply embedded in human and business activities. In this SI, we offer a glimpse of what that variety might be for management scholars from across the globe.

Sustainability, well-being, entrepreneurship, and innovation have long been central themes in management studies, albeit with varying degrees of intensity and trends. To get a sense of the interest in these themes, we performed a search within the Web of Science database. We performed a search of the four terms within all type of documents and delimited our search to the time interval 2000-2020. To get an immediate sense of our results, we arranged them in Figure 1. 


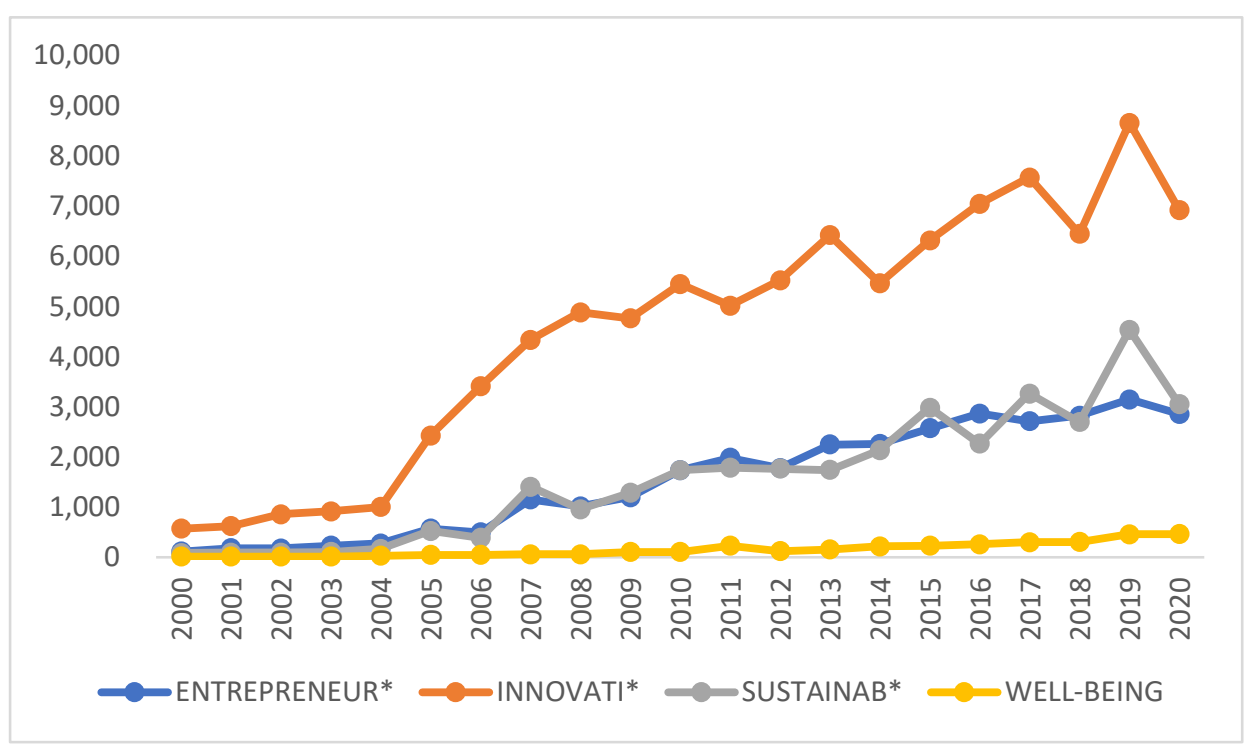

Figure 1. Management articles published between 2000 and 2020 on our SI themes.

Figure 1 displays that the number of management articles published for each theme has been continuously increasing since 2000. It is noteworthy that: (a) the term 'innovation' continues to increase at a quicker pace than ever; (b) the terms 'entrepreneurship' and 'sustainability' are on an irreversible upward trajectory, even if they do not occur together as frequently in research works (less than $20 \%$ from 2010 to today).

To understand what it is that stands beneath these figures, we develop our reflections along two different lines. The first one is related to the nature and notional definitions of our four pillars. The second one is related to the linkages between entrepreneurship and innovation and the grand challenges.

Our four pillars of this SI are all umbrella terms or hembigs: Umbrella constructs are broad and ambiguous terms that stand for a variety of notional definitions and encompass a multitude of substantive phenomena [5]. In a similar vein, hembigs are big and ambiguous constructs that have become hegemonic in management and organization studies [6]. Entrepreneurship, innovation, sustainability and well-being are all general terms; they do not have a unitary or universal connotation and display multiple meanings and dimensions. While presented as singular concepts, they stand for a variety of definitions and vary over time and space. The umbrella nature explains the massive interest these topics have received so far, but also the difficulties of systematizing knowledge in the field. One way to achieve this aim is to reconstruct their different notional definitions.

Pursuing innovative solutions to improve well-being or address sustainability challenges involves industries including fashion and apparel, chemical, pharmaceutical or logistics and transportation which typically create tensions between increasing economic/financial value and preserving the natural environment [7-10]. Moreover, they require customized solutions to achieve such a balance [11]. Solving these grand challenges is not a solitary endeavor, but rather a collective, open, and multi-stakeholder one that requires cooperation across disciplinary as well as institutional boundaries [12,13]. Companies may play an active role in the search and the development of sustainable innovations and provide viable solutions to collective and global problems such as climate change, food security and population aging [14-16].

Studies on sustainable innovation highlight the multidimensional nature of this concept: sustainable innovation may involve either product/process or organizational/business model innovations to reduce or stabilize impacts from a social, environmental, and economic point of view [17-19]. Green innovation, eco-innovation, and responsible innovation are just some of the variations that have been recently emerging from the literature on the subject $[20,21]$ and are expected to raise additional interest in the near future. 
Relatedly, sustainable entrepreneurship is also a broad field that can be defined as "a unique perspective that combines the creation of environmental, social and economic values, which focuses on ensuring the well-being of future generations" [10]. Companies are called upon to combine economic sustainability with environmental and social needs by harnessing them into their strategies and balancing the managerial requests for economic viability with these emerging requirements $[15,22]$. This poses cultural, strategic, and organizational challenges to entrepreneurs and managers [23,24]. Some recent studies have thoroughly dissected or even expanded the concept of sustainable innovation [25], advancing new terms, such as sustainopreneurship [26], social entrepreneurship, and environmental entrepreneurship [27]. They all offer opportunities for future research, an issue we will return later in this editorial.

Last, but not least, well-being is also a broad, umbrella term that encompasses physical and psychological dimensions, subjective as well as individual and collective ones. Like the notion of sustainability, well-being offers multiple opportunities for interdisciplinary research that combine medicine and psychology with social sciences, including management or public policy. More and more, well-being is considered as a dynamic concept, changing across individuals' lives and affected by surrounding conditions. Again, COVID-19 has raised the attention on the importance of preserving individual well-being under extreme conditions, like social distancing and remote working with very limited social interactions. Well-being can also be seen as a holistic term related to good quality of life, an antecedent of health, again in broad sense. What the next normal will look like also depends on how governments, companies, non-profit organizations, and other institutions will take the responsibility of caring about well-being and the solutions they will implement in our daily lives.

\section{Inside Our Special Issue: A Snapshot of Our Papers}

Our call for paper has raised interest and produced a number of submissions addressing a variety of topics and perspectives. Papers are arranged in alphabetical order in Table 1, where we also note the main focus, method, theoretical perspective, and level of analysis.

Table 1. An overview of SI papers.

\begin{tabular}{|c|c|c|c|c|}
\hline Authors & Pillars Covered & Level of Analysis & Method & Theoretical Frameworks \\
\hline Anaya-Aguilar et al. & E-I-WB & Individual & Survey & $\begin{array}{l}\text { Business model } \\
\text { Stakeholder lens }\end{array}$ \\
\hline Capobianco et al. & S-I & Institutional & Qualitative interviews & PESTLE \\
\hline Cosimato and Vona & S-I & Organizational & Literature review & $\begin{array}{c}\text { Strategic decision-making } \\
\text { drivers }\end{array}$ \\
\hline Fang et al. & E-S-I & Individual & Survey & $\begin{array}{l}\text { Psycho ownership, green } \\
\text { innovation and creativity }\end{array}$ \\
\hline Makhloufi et al. & E-I & Organizational & Cross-sectional survey & $\begin{array}{c}\text { Absorptive capacity, } \\
\text { organizational learning }\end{array}$ \\
\hline Ruozzi and Vicente & E-S-I & Institutional & FsQCA & Institutional conditions \\
\hline
\end{tabular}

Taken together, these papers emphasize that entrepreneurship and innovation contribute both economic and societal growth and that the underlying processes are intertwined with environmental and social protections. At a closer look, the papers indicate that different levels of analysis are covered with different theoretical frameworks. Below, we provide more details about each paper, following the alphabetical order of the table.

In their paper "A typology of spa-goers in Southern Spain", Anaya-Aguilar and colleagues deal with physical well-being arising from thermal tourism. Through a survey among Andalusian spa-goers, they point to the importance of better defining the customer value proposition to attract different tourist segments and innovative services, including therapies based on relaxation and sustainable natural tourism. The study highlights how 
a mature industry can be innovative by embracing notions of sustainability and green tourism to rethink traditional customer value propositions.

In their paper "Towards sustainable decommissioning of offshores platforms in the oil and gas industry: A PESTLE analysis", Capobianco and colleagues focus on sustainability in oil and gas industries and address the decommissioning of offshore platforms. The study provides a Political, Economic, Social, Technological, Legal, and Environmental analysis based on semi-structured interviews with oil and gas key informants and stakeholders in Italy. Their findings provide a novel thinking for pursuing a sustainable decommissioning of offshore platforms and shed light on the importance of synergistic efforts by local entrepreneurship and institutional arrangements.

In their paper "Digital innovation for the sustainability of reshoring strategies: A literature review", Cosimato and Vona conduct a systematic review on shoring decisions including re-shoring ones. They focus on motivations or drivers for making reshoring strategies sustainable and employ a structured and narrative literature review. Their findings contribute to better defining reshoring and disentangle what some drivers, especially digital innovation, can play on related strategies and on their sustainability. In doing so, this work jointly approaches reshoring, sustainability, and digital innovation.

In their paper "What could entrepreneurial vision do for sustainable development? Explore the cross-level impact of organizational members' green shared vision on green creativity", Fang and colleagues explore the relationships among an organization's GSV, green product psychological ownership (GPPO), proactive green innovation (PGI), reactive green innovation (RGI), and green creativity (GC) in Taiwan. The results obtained from a survey indicate that team-level GSV has a positive and significant relationship with GPPO and GC at the individual level. As an important implication, an organization should develop a green shared vision among its members to facilitate green innovation and enhance the green creativity of its members.

In their paper "Impact of entrepreneurial orientation on innovation capability: The mediating role of absorptive capability and organizational learning capabilities", Makhloufi and colleagues focus on absorptive capacity and organizational learning capabilities to investigate their relationship with entrepreneurial orientation and innovation capabilities. Drawing upon the dynamic capability theory, the study applies a cross-sectional survey targeting Algerian firms. The findings highlight that absorptive capacity and organizational learning capabilities serve as connectedness mechanisms and link external knowledge and internal learning processes to accompany entrepreneurial orientation readiness during innovation development.

In their paper "Entrepreneurial framework conditions and impact scores of smallsized certified benefit corporations (CBCs). A configurational analysis of 17 countries", Ruozzi and Vicente aim to understand the country conditions that could promote sustainable innovation in small Certified B Corporations (CBCs). They employ a fuzzy-set qualitative comparative analysis to identify the combinations of presence/absence of four entrepreneurial framework conditions (EFCs) - financing for entrepreneurs, taxes and bureaucracy, R\&D transfer, and commercial and legal infrastructure- that are sufficient for the presence/absence of a high average impact score of small-size CBCs in the country. The analysis reveals that two combinations of the presence/absence of the considered EFCs are sufficient for the presence, and another two are sufficient for the absence of that outcome.

\section{Where Do We Go from Here? Towards a Research Agenda}

In closing our editorial, we would like to offer our own view on future research dealing with the four pillars inspiring our CfP. The considerations we have offered here have just scratched the surface of complex, multifaceted, multilayered, and inherently dynamic phenomena. We believe that there is room for additional research within each pillar and at the intersection of these pillars. Here we offer a few considerations to foster additional inquiry. We depart from the umbrella nature of these constructs and move on substantive phenomena. 
Despite the wealth of studies on sustainable innovation and sustainable entrepreneurship, further research is needed to deepen the notional definitions of entrepreneurship and innovation mixed with sustainability and well-being, towards construct clarity [28]. Disentangling such variety is an important starting point to identify multiple avenues for future research related to the multiple dimensions these constructs harness.

Much work can still be done to identify formulas that balance economic viability with environmental and social goals, for example, by analyzing specific contexts and conditions that can foster the development of sustainable innovation and entrepreneurship, as well as the impact that these factors may have on regional development. Additionally, future research may shed light on factors or variables influencing customers' propensity to purchase sustainable products and services.

Another important way to move research forward is embracing a stakeholder perspective [29], which allows investigation into how these constructs may assume different connotations depending on the stake or the stakeholder we take into account. The distinction between stake and stakeholder is extremely important when we deal with sustainability as environmental protection. While the environment has multiple, often powerless stakeholders, it nevertheless represents an important stake to protect.

Embracing a stakeholder lens implies recognizing that societal, grand challenges require a joint effort from multiple actors. Focusing on the organizational level of analysis should be augmented by meso and macro levels of analysis that include public-private partnerships, involving governmental or non-profit agencies along with big companies [30].

Digging deeper into these pillars would benefit from adopting different and complementary perspectives, and from analyzing antecedents, moderating/mediating and outcome variables. Such an investigation could further our understanding of processes and mechanisms driving entrepreneurial and innovative processes that foster well-being and sustainability, and contribute to the advancement of knowledge and impact on society.

In closing, we contribute to enriching research on important topics that matter to individuals, companies, and society at large. We hope our readers benefit from the insights and findings in our papers. There is a long way to go!

Author Contributions: Authors contributed equally to this manuscript. Both authors have read and agreed to the published version of the manuscript.

Funding: This research received no external funding.

Institutional Review Board Statement: Not applicable.

Informed Consent Statement: Not applicable.

Data Availability Statement: Not applicable.

Conflicts of Interest: The authors declare no conflict of interest.

\section{References}

1. Meglio, O.; Di Paola, N. Innovation and Entrepreneurship for Well-Being and Sustainability. Available online: https://www. mdpi.com/journal/sustainability/special_issues/innovation_entrepreneurship_well-being (accessed on 1 August 2021).

2. World Health Organization. COVID-19 Public Health Emergency of International Concern (PHEIC). Global Research and Innovation Forum: Towards a Research Roadmap; World Health Organization: Geneva, Switzerland, 2020.

3. Caballero-Morales, S.O. Innovation as recovery strategy for SMEs in emerging economies during the COVID-19 pandemic. Res. Int. Bus. Financ. 2021, 57, 101396. [CrossRef]

4. Hakovirta, M.; Denuwara, N. How COVID-19 redefines the concept of sustainability. Sustainability 2020, 12, 3727. [CrossRef]

5. Hirsch, P.M.; Levin, D.Z. Umbrella advocates versus validity police: A life-cycle model. Organ. Sci. 1999, 10, 199-212. [CrossRef]

6. Alvesson, M.; Blom, M. The hegemonic ambiguity of big concepts in organization studies. Hum. Relat. 2021, in press. [CrossRef]

7. Hagedoorn, J. Innovation and entrepreneurship: Schumpeter revisited. Ind. Corp. Chang. 1996, 5, 883-896. [CrossRef]

8. Baumol, W.J.; Robert, J.S. Entrepreneurship and economic growth. Strategy Entrep. J. 2007, 1, 233-237. [CrossRef]

9. Urbano, D.; Aparicio, S.; Audretsch, D. Twenty-five years of research on institutions, entrepreneurship, and economic growth: What has been learned? Small Bus. Econ. 2019, 53, 21-49. [CrossRef]

10. Terán-Yépez, E.; Marín-Carrillo, G.M.; del Pilar Casado-Belmonte, M.; de las Mercedes Capobianco-Uriarte, M. Sustainable entrepreneurship: Review of its evolution and new trends. J. Clean. Prod. 2020, 252, 119742. [CrossRef] 
11. Sarango-Lalangui, P.; Santos, J.L.S.; Hormiga, E. The development of sustainable entrepreneurship research field. Sustainability 2018, 10, 2005. [CrossRef]

12. Adams, L.V.; Wagner, C.M.; Nutt, C.T.; Binagwaho, A. The future of global health education: Training for equity in global health. BMC Med. Educ. 2016, 16, 1-7. [CrossRef]

13. Owen, R.; Bessant, J.R.; Heintz, M. (Eds.) Responsible Innovation: Managing the Responsible Emergence of Science and Innovation in Society; John Wiley \& Sons: Hoboken, NJ, USA, 2013.

14. Franceschini, S.; Faria, L.G.; Jurowetzki, R. Unveiling scientific communities about sustainability and innovation. A bibliometric journey around sustainable terms. J. Clean. Prod. 2016, 127, 72-83. [CrossRef]

15. Lubberink, R.; Blok, V.; Van Ophem, J.; Omta, O. Lessons for responsible innovation in the business context: A systematic literature review of responsible, social and sustainable innovation practices. Sustainability 2017, 9, 721. [CrossRef]

16. Urbaniec, K.; Mikulčić, H.; Wang, Y.; Duić, N. System integration is a necessity for sustainable development. J. Clean. Prod. 2018, 195, 122-132. [CrossRef]

17. Claudy, M.C.; Peterson, M.; O'driscoll, A. Understanding the attitude-behavior gap for renewable energy systems using behavioral reasoning theory. J. Macromark. 2013, 33, 273-287. [CrossRef]

18. Boons, F.; Lüdeke-Freund, F. Business models for sustainable innovation: State-of-the-art and steps towards a research agenda. J. Clean. Prod. 2013, 45, 9-19. [CrossRef]

19. Schaltegger, S.; Lüdeke-Freund, F.; Hansen, E.G. Business models for sustainability: A co-evolutionary analysis of sustainable entrepreneurship, innovation, and transformation. Organ. Environ. 2016, 29, 264-289. [CrossRef]

20. Di Paola, N.; Russo Spena, T. Navigating the tensions in environmental innovation: A paradox perspective. Eur. J. Innov. Manag. 2020. [CrossRef]

21. Spena, T.R.; Di Paola, N. Moving beyond the tensions in open environmental innovation towards a holistic perspective. Bus. Strategy Environ. 2020, 29, 1961-1974. [CrossRef]

22. Belz, F.M.; Binder, J.K. Sustainable entrepreneurship: A convergent process model. Bus. Strategy Environ. 2017, 26, 1-17. [CrossRef]

23. Ploum, L.; Blok, V.; Lans, T.; Omta, O. Toward a validated competence framework for sustainable entrepreneurship. Organ. Environ. 2018, 31, 113-132. [CrossRef]

24. Vuorio, A.M.; Puumalainen, K.; Fellnhofer, K. Drivers of entrepreneurial intentions in sustainable entrepreneurship. Int. J. Entrep. Behav. Res. 2018, 24, 359-381. [CrossRef]

25. Muñoz, P.; Cohen, B. Sustainable entrepreneurship research: Taking stock and looking ahead. Bus. Strategy Environ. 2018, 27, 300-322. [CrossRef]

26. Aghelie, A.; Sorooshian, S.; Azizan, N.A. Research gap in sustainopreneurship. Indian J. Sci. Technol. 2016, 9, 1-6. [CrossRef]

27. Anderson, A.R. Cultivating the Garden of Eden: Environmental entrepreneuring. J. Organ. Chang. Manag. 1998, 11, 135-144. [CrossRef]

28. Yaniv, E. Construct clarity in theories of management and organization. Acad. Manag. Rev. 2011, 36, 590-592. [CrossRef]

29. Parmar, B.L.; Freeman, R.E.; Harrison, J.S.; Wicks, A.C.; Purnell, L.; De Colle, S. Stakeholder theory: The state of the art. Acad. Manag. Ann. 2010, 4, 403-445. [CrossRef]

30. Scherer, A.G.; Palazzo, G. The new political role of business in a globalized world: A review of a new perspective on CSR and its implications for the firm, governance, and democracy. J. Manag. Stud. 2011, 48, 899-931. [CrossRef] 